\title{
Forging communities: coalitions, identity symbols and ritual practices in Eastern Iberia Iron Age
}

\begin{abstract}
The investigation of settlement dynamics in the Eastern Iberian Iron Age highlights the formation of coalitions, with inhabitants of several sites coming together under the control of Iberian towns. Ideological strategies and ritual practices served to promote a sense of community and to sustain the new political order. The creation and recreation of a collective identity was largely accomplished through the construction of a sacred landscape with local sanctuaries. In addition, complex pottery iconography, related to ritual practices, contributed to an ongoing process of aggregation of individuals within larger communities.
\end{abstract}

\section{Keywords}

Iberian Peninsula; Iron Age; city-states; sacred landscape; iconography; ritual

\section{Introduction}

The Iron Age in the Iberian Peninsula $\left(8^{\text {th }}\right.$ to $1^{\text {st }}$ centuries $B C$ ) is characterized geographically by a division into two large regions. The Central, Western and Northern region had Indo-European roots and the Southern and Eastern parts of the Peninsula, with Mediterranean influences, that corresponds to the Iberia named by classical writers during the period of the Roman conquest. Within these large cultural areas it is possible to observe a noticeable regional variation in the organization of cultural, political and economic forms (Ruiz 2008).

This paper focuses on the central Mediterranean area of Iberia (Fig. 1) characterized by the development of complexity with patron-client forms of social relationships, the emergence of urbanism, early states and economic development with interregional exchange. The introduction of lberian local economies into the Mediterranean exchange system has been implicated in the development of complex socio-political systems (Ruiz 2008). Iberian elites enacted strategies including patronclient relationships, prestige goods exchange systems, aristocratic control of rituals and commensality or competitive feasting (Ruiz and Molinos 1998; Grau Mira 2011).

Landscape and settlement pattern studies illustrate the dynamics of centralization and urbanization of Iberian communities. In this process a series of medium-sized urban sites, generally between 1 and 10 hectares, were remarkably important in shaping landscapes. These sites are named oppida, a Latin term adopted to describe fortified nuclei generally built in prominent locations that facilitated visual control over the surrounding countryside and nearby subordinate rural settlements. These sites housed large numbers of people including Iberian elites. However, this general settlement trend exhibited regional differences across Mediterranean Iberia with respect to differences in political and social organization (Ruiz and Molinos 1998; Bonet, Grau and Vives-Ferrándiz 2015; Sanmartí 2009).

The oppida were not isolated polities; they functioned as loci that allocated local power within the Iberian region. The complex links between each oppida served to configure Iberian coalitions that led to new political entities and the development of Early States during the $3^{\text {rd }}$ cent. BC (Bonet, Grau and Vives-Ferrándiz 2015; Ruiz 2008).

\section{Iberian coalitions from ancient text}


According to information from classical writers, some form of Iberian coalitions may have been operating in the moments before first contact between the Iberians and Rome. Polybius (10.40-3, quoted in Bonet 1995) says that King Edecon, a name usually associated with the Iberian town of Edeta (EI Tossal de Sant Miquel in Llíria, Valencia), asked the Roman general Scipio to liberate his family and promised, in return, that all Iberian peoples south of the River Ebro would ally with Rome. This assertion implies an association of different peoples into a coalition that recognized the authority of Edecon. In Southern Iberia, Polybius says, at different times, that King Culchas' confederation consisted alternatively of 28 and 17 oppida (Polybius 10.3-4, quoted in Ruiz 2008). These writings show that the territories of the Iberian oppida were clustered into large coalitions, covering extensive regions.

These texts refer to the context of the Second Punic War in which Iberia was the battlefield and the Iberian peoples were involved dramatically in the confrontation between the Carthaginians and the Romans during the late $3^{\text {rd }}$ century $\mathrm{BC}$. It is possible that these coalitions may have been created as a result of this war, however, they more likely reflect existing networks that facilitated these military coalitions. Nevertheless, because these ancient texts often only refer to historical events that were interesting from the point of view of Roman writers, information related to the Iberian perspective is obscured.

The nature of Iberian coalition formation is usually described as being based on personal links between community leaders through the lberian institutions of the fides and devotio. These are religious institutions which link people in patron-client relationships (Ruiz 2008). However, this interpretation is unsatisfactory because it does not explain how these links became effective, nor does it explain the participation of non-elites in these forms of social aggregation.

In the following pages, I present the emergence of large polities through the coalition of several oppida as evidenced by settlement dynamics. Secondly, I propose ideological strategies and ritual practices used to promote a sense of community in the new political order. Every political structure needs an imagined value system and ideology to legitimize the political order. In doing so, the material culture, ranging from monuments to portable objects, used daily and in ritual practice, contributes to effectively fixing this collective habitus (Bourdieu 1980, 191; DeMarrais, Castillo and Earle 1996, 16). I will focus specially on Iberian landscapes that, as in other Mediterranean contexts, "provide the broad physical framework that shaped communal experience" (Alcock 2002, 31). The process of identity construction is especially significant in times of sociocultural and political transition, when frequently collective identities are transformed (Yoffee 2007, 3).

\section{Coalitions in Iberian landscapes}

The aggregation of different Iberian communities is based on the archaeological study of landscape and settlement patterns. One of the clearest trajectories toward coalition in the form of a new political unit comes from the Alcoi Valley, a geographical area in the central-southern part of the modern Valencian Region. This area constitutes a moderately mountainous region close to the eastern coast of the Iberian Peninsula. The Alcoi Valley was the ancient territory of the Iberian town of La Serreta, a site that has been largely excavated and its territory intensively surveyed. The fieldwork carried out during the last decades allows us to understand the settlement dynamics that contributed to the constitution of this Iberian landscape (Grau Mira 2002, 104-109).

This territory was developed in two stages. During the Early and Middle Iberian Periods $\left(7^{\text {th }}-4^{\text {th }}\right.$ centuries $\left.B C\right)$ the region was structured around a series of small territories dominated by local oppida (Fig. 2). These urban centres controlled dependent farming settlements of different sizes that existed in each valley, ranging from what may have been family farmsteads to larger villages or hamlets (Grau Mira 2002, 119-121). Conflicts and social tensions between oppida were frequent during this period as archaeological levels of destructions prove (Grau Mira 2002). 
The second stage was directed toward the union of several different polities to create a large political unit. During the $3^{\text {rd }}$ century BC one of the existing oppida, La Serreta, increased in size, functioned as a religious and political centre, and was raised to the category of capital town of the valley. However, in terms of territorial organization, the other oppida continued to serve as local centres for each of the valleys. The surrounding rural sites increased in number in order to sustain this early Iberian city-state (Grau Mira 2002).

The Alcoi Valley is an example of the process of polity aggregation and the construction of a new political structure. The Eastern Iberia region experienced similar processes resulting in a trajectory toward the configuration of city-state-based societies and centralized political institutions. Studies carried out some in different areas had already revealed the political processes leading to the configuration of archaic states. It has been proposed that a series of Iberian towns would have been at the pinnacle of the territory on a regional scale (Fig. 1).

In the north of the study area, the political territory was structured around the Iberian town of Edeta, located on a hilltop called El Tossal de Sant Miquel in Llíria in the Valley of the river Turia (Valencia province) (Fig. 1, 1). This oppidum was the territorial central place from the Early Iron Age. During the $3^{\text {rd }}$ century BC, Edeta consolidated its commanding position and controlled other sites where elites resided such as El Castellet Bernabé and El Puntal dels Llops (Bonet 1995).

Further south was the territory of the Iberian town of Saitabi, (modern Xàtiva) in the valley of the river Canyoles (Valencia province) (Fig. 1, 2). During the $3^{\text {rd }}$ century BC, Saitabi controlled several oppida and subordinate rural sites. It was one of the most important settlements of the region and was notable for its size, covering an area of 8 hectares, as well as the minting of silver coins during the $3^{\text {rd }}$ century BC (Pérez Ballester 2011).

The lberian town of Allon was located beneath the present-day town of La Vila Joiosa (Fig. 1, 4). It was an important coastal center with solid relationships with Mediterranean traders and controlled the Iberian territory corresponding to the current county of La Marina Baixa since Early Iberian period (Rouillard, Espinosa and Moratalla 2014).

The Vinalopó Valley (Alicante Province) was the territory controlled by the Iberian town of Ilici (Fig. 1, 5). It was one of the most important Iberian towns and the place where the famous sculpture known as the Lady of Elche was discovered. Ilici was the capital of an extensive territory covering around $1500 \mathrm{sq} \mathrm{km}$ occupied by secondary oppida and rural villages. Important collections of lberian sculptures, figured pottery and other notable archaeological elements reveal the town's importance since the $4^{\text {th }}$ cent. BC (Moratalla 2005).

In the region of Hellín, further inland in the province of Albacete, was located the Iberian town of El Tolmo de Minateda, possibly the ancient town of Ilunum (Fig. 1, 7). This town controlled other secondary centers and guarded the important routes between the inland Meseta and the South-eastern coast since early lberian period, but increased its importance during the $2^{\text {nd }}$ and $1^{\text {st }}$ cents. BC (Abad and Sanz 1995).

In the southern part of the study area, several important oppida such as Coimbra del Barranco Ancho (Fig. 1, 6), Verdolay (Fig. 1, 9), El Cigarralejo (Fig. 1, 10) or La Encarnación de Caravaca (Fig. 1,11) were controlling the local territories and the communication networks of the region during the $4^{\text {th }}$ and $3^{\text {rd }}$ centuries BC (García Cano 1997).

\section{Coalitions in practice: creating sense of community}

In the settlement pattern for the whole region of Central Mediterranean Iberia we can see a common evolution towards the establishment of political units, in which various communities and local powers were brought together under a capital town. This would have meant doing away with the local community structures established by each oppidum and defining a new societal structure during the $3^{\text {rd }}$ cent. BC. This process has been studied in-depth in the Valencia Region, which covers the northern part of the 
study area (Bonet, Grau and Vives-Ferrándiz 2015). However, further investigations are needed to detail the political dynamics that unfolded in he southern part of the region.

Iberian urban territorial organisation in this part of the Iberian Peninsula developed largely in the $3^{\text {rd }}$ century BC and would have been influenced in the $2^{\text {nd }}$ and $1^{\text {st }}$ centuries $\mathrm{BC}$ by the introduction of Roman rule. Far from bringing it to a halt, Rome fostered the process of establishing communities and territories and encouraged the use of native traditions, which were reinvented in the new social context.

As part of that process it was necessary employ social strategies to set up an "imagined community" (Anderson 1991); in other words, the construction of a new political entity required symbols that provided authenticity based on shared collective traditions and values (Hobsbawm 1983). This was an active process of ethnic identity creation (Jones 1997), materialised in ritual practices (DeMarrais, Castillo and Earle 1996) that evoked shared memories and used them to justify the new political framework and its landscape (Yoffee 2007). In the following pages I discuss these ideological and ritual practices as political strategies

\section{Polities and sacred landscapes}

Endowing sacred approval on political territories by building sanctuaries has been identified as a common phenomenon in the territorial configuration of the Mediterranean region (De Polignac 1984). Far from being immutable, religious practices were manipulated so that they could play an active role in the construction of the ideological messages that maintained the social order of the time.

During the process of aggregating the different oppida under broad coalitions of a regional nature, the ritual spaces of each oppidum, such as the necropolises, were replaced by a limited number of sanctuaries that brought together the ritual activities of various oppida (Fig. 3). One of the most interesting examples of the emergence of sanctuaries to sanction the process of establishing a new political entity can be seen in the Alcoi Valley. During the $5^{\text {th }}$ and $4^{\text {th }}$ centuries -the period in which local powers ruled- the main places of worship were necropolises linked to oppida and sacred caves located in peripheral areas of the territory.

The necropolises are one of the main sources of evidence relating to ritual activity in the period of formation and consolidation of the oppida, especially in the $4^{\text {th }} \mathrm{C}$ BC. The most important oppida as La Serreta, Allone or llici had a necropolis where the elites were buried, accompanied by their relatives and their clients. Cults and rites venerating ancestors were performed in these funerary spaces, which become important places of memory related to the construction of the social order of the oppidum linked to the local powers.

Concerning the sacred caves, in some of the cavities in the region have been documented ritual practices in which hundreds of pottery cups, small personal adornments and other offerings were deposited. The caves were visited by the inhabitants of the nearby oppida on ritual journeys that distanced them from daily life and took them into the forested limits of the territory, probably in ceremonies linked to initiation rites (Grau and Amorós 2013).

In the $3^{\text {rd }}$ century $B C$ a decline in the use of these necropolis and ritual caves is documented, almost to the point of disuse, while a new sanctuary was built in the town of La Serreta, on the highest part of the hill where this town was located (Visedo Molto 1922). This sacred place replaced the earlier sacred caves in serving the religious needs of the territory. It would have been visible from anywhere in the territory, a visual prominence that would have reinforced the relationship between the capital and the other populated areas in its territory (Fig. 4).

La Serreta d'Alcoi exemplifies the emergence and rise in importance of places of worship linked to the reconfiguration of the territories in Iron Age Eastern Iberia. In the next section, It would be of interest therefore to review the main sites and features that allow us to reconstruct the process 


\section{Common beliefs, common offerings}

The relationships established by the faithful with their divinities were expressed in many ways, most of which have left little or no archaeological evidence. Processions, prayers, vows and compliance, the contemplation of images and oracular consultations can all be assumed to have taken place at the worship places, but without leaving archaeological traces. As a matter of fact, communication with divinities is mainly expressed in the archaeological remains as deposits of offerings and exvotos (Aranegui 2012). The Iberian sanctuaries in the study area are characterised by being formed mainly of sacred deposits, normally buried in the ground. They are usually recorded as favissae or bothroi -using classical terminology- and in the majority of cases are simple pits in which the offerings were buried.

A detailed analysis and interpretation of these votive offerings is beyond the scope of this paper; here, the focus is a single aspect that appears to be particularly important as a strategy for strengthening community identity. A specific type of object was chosen to be deposited as an offering for each territorial sanctuary. The objects were not normally of a single, exclusive type, but there is clear evidence of the selection of a different object to that of neighbouring cult places. This selection of a specific object for each sanctuary represented a change from the earlier practice of offering similar ceramic cups at all the region's caves. In this way the sense of belonging to a particular territory was expressed through the deposit of a specific offering in each place.

As an example, La Serreta d'Alcoi sanctuary, located at the summit of the town, had a sacred deposit of more of four hundred terracotta figurines (Fig. 5). At least four major types of item were recovered: female-head-shape incense burners, compositions of groups of figurines, figurines representing male heads and, the most abundant, female figurines. The predominant female presence has been linked to fertility worship at the sanctuary, a hypothesis strengthened by the find in the town of the image of a female nurturing divinity. The presence of various types of terracotta figures, as well as other ritual objects, provides an indication of the diverse identities of the audience at the sanctuary, with expectations and motivations expressed through diverse practices. However, over and above the variation, the fact that the majority of the offerings are figurines made with local clay identifies this sanctuary and differentiates it from its neighbours.

A brief review of other votive deposits at Eastern Iberia confirms the pattern of differentiation in offerings. The sanctuary of La Carrasposa, located on a hillock near the Iberian town of Saitabi (Fig. 3), contained an extensive collection of near one hundred terracotta figurines depicting animals, mainly oxen, horses and rams. Other votive offerings, such as pottery vessels linked to ritual meals, accompany the clay figures. The animal figurines are interpreted as offerings to a protector deity to favour the fecundity of the cattle (Pérez and Borreda 2004).

On a particularly high hill near the town of Coimbra del Barranco Ancho (Figure 3) a sacred deposit consisting mainly of near sixty female-head-shape incense burners was associated with an agricultural deity. Together with these predominant items were found small precious metal plates depicting masks (García Cano, Iniesta and Page 1997).

These small metal sheets, as well as other gold and silver items, are particularly common at the sanctuary of La Encarnación (Fig. 3), near the Iberian town of Los Villaricos. The find of almost one hundred pieces of precious metal characterises this place of worship. Other votive offerings documented with them include fibulas and some sculptures. Analyses of microscopic sediments also show that libations of milk and honey took place at this site (Brotons and Ramallo 2010).

The sanctuary of El Cigarralejo (Fig. 3) adjacent to a large complex made up of the settlement and an extensive burial site, is characterised by a votive deposit dated to around the $2^{\text {nd }}$ century BC consisting of almost two hundred small sandstone carvings. They are mainly sculptures and bas-relief horses and, to a lesser extent, 
human figures. The assemblage is accompanied by other offerings including rings and fibulas. The frequency of the horse figures has been interpreted as offerings to a protector divinity of horses (Lillo, Page and García 2004).

At the sanctuary of La Luz in Verdolay (Fig. 3) there was a ritual deposition of near seventy bronze figurines, which were found wrapped in (possibly linen) cloth, placed upside down and obscured by a layer of mud. These predominantly bronze exvotos were accompanied by other pieces, such as small votive falcatas swords, rings and a large assemblage of pottery, possibly linked to ritual meals (Tortosa and Comino 2013).

Finally, the sanctuary of La Malladeta near the Iberian town of Allone (Fig. 3) yielded numerous fragments of incense burners associated with a female divinity, mainly from the later archaeological strata. Such circumstances make it difficult to accurately interpret the sites, but they leave no doubt as to the existence of a sanctuary where offerings of terracotta incense burners were deposited (Rouillard, Espinosa and Moratalla 2014).

The existence of these characteristic types of offering at each sanctuary can be explained by different ways of worshipping the divinities, with symbols appropriate to the divine figure of protection that would have made up the ritual prescriptions. Specialist workshops associated with each sanctuary would also have contributed to the commoditization of the offerings. However, there can be no doubt that they contributed to the development among those making the offerings of a sense of shared practice and the experience belonging to a community of practitioners

Sacred journeys

One of the most significant ritual practices that can be reconstructed from the model of sanctuaries in the centre of the territory is that of the pilgrimage or ritual journey. Assuming that devotees travelled from various oppida and settlements in the county to the cult place to attend events or festivities, those walks would have taken on a ritual form. As such they would have constituted "territories of grace", i.e. zones defined by the sanctuary's radius of action that would have attracted the people of the surrounding area (Morinis 1992 18-25). These territorial sacred areas would have involved journeys that could be made in a single day.

Archaeo-astronomical studies at these sacred places have led to the conclusion that their astronomic orientations are linked to farming calendars and the annual growing cycles. It has been hypothesised that the principal pilgrimage period would have been around the autumn equinox, the time for harvesting and expressing gratitude to the divinities (Esteban 2013). A pilgrimage would have formed part of a calendar of festivities (Morinis 1992, 4-5), although it is possible that the sanctuary was visited for other reasons.

The anthropological and archaeological hypotheses show that both the sacred place and the pilgrimage would have acted as factors of social cohesion (Alfayé 2010; López-Bertran 2011). Sacred journeys were ritual mechanisms of integration that brought together different groups and communities on the basis of shared ritual experiences expressed through community practices (Sallnow 1981, 163-182). As we have already pointed out, this does not imply complete uniformity in the ceremonial rituals or forms, as the participation of varied and diverse audiences would have been expressed through a plurality of discourses and actions (Alfayé 2010, 183). Nevertheless, the common elment, a ritual journey to a central place -on the same dates and to participate in the same festivals- would have contributed to a common identity among the populations of a territory.

\section{Images and communities}

One of the most noticeable cultural expressions in the study area is the appearance and development of a rich iconography with complex scenes and figures on pottery. These images date to the same period of the formation of urban landscapes 
just described. The first styles appeared in Edeta and La Serreta in the $3^{\text {rd }}$ century BC and the others were developed during the $2^{\text {nd }}$ and $1^{\text {st }}$ centuries BC (Aranegui 2012).

Styles and territories

Current research has transformed the traditional view that Iberian figuredecorated pottery consists only of two large styles, the narrative and the symbolic, that covering extensive regions. Today these two broad stylistic categories are divided into local styles based on differences in forming techniques, themes, and shapes of vessels. Among the stylistic groups, those of Edeta (Aranegui, Pérez and Mata 1997; Bonet 1995), La Serreta of Alcoi (Grau Mira 2007), Allon (Pérez Blasco 2011), Ilunum (Abad and Sanz 1995), different styles in the Iberian town of Ilici, and another developed in Murcia Region (Tortosa 2006) are significant to this discussion (see Fig. $6)$.

\section{Pottery in Rituals}

The Iberian decorated pottery has common shapes used for storage and to serve food, but the rich decoration was used to mark special events, as seen in other archaeological contexts (DeMarrais and Robb 2013, 12). It has been discovered mainly in the towns and the principal sites of the territory inhabited by the elites (Aranegui, Pérez and Mata 1997). The themes depicted and their appearance in domestic shrines show that the vessels were used in ritual contexts and for the ideological representation of the elites; however, the images may involve multiple participants who were forged bonds of solidarity through shared action (DeMarrais and Robb 2013, 12).

\section{Local heroes}

The images and visual language contributed to the creation of a sense of community through a shared mythology and system of beliefs. Some of the most noticeable examples show complex narrations of legendary histories. One example recently studied is the so-called Vase of the Warriors of La Serreta of Alcoi (Fig. 7). This vase shows the narration in three episodes of the initiation of a young aristocrat (Olmos and Grau 2005). The hero usually is represented fighting against the local beast (García Cardiel 2014), revitalising old myths and seeking the protection of tradition. These scenes are found in examples all around the region.

The history of the Iberian heroes and other mythological narrations were transmitted through these depictions. Legends of the founder-hero of the lineage, linked to ancestor's cult, allowed the consolidation of the aristocracies. The preeminence of certain families was based on their direct hereditary links with the founderhero and these relationships consolidate their privileged social position. Local aristocracies used the memory of these legendary histories to claim the heritage of an ancient leader, to justify the hegemony of a town, or to legitimize a political process (García Cardiel 2014, 642).

Therefore, the act of viewing and remembering the myth could have promoted the idea of collectivity (DeMarrais 2011). These aspects of cultural memory and belief were fundamental cognitive and symbolic resources in the construction of the Iberian social order.

\section{Conclusions}

Ritual practices were integral to the the formation of city-state polities in Eastern Iberia during the $3^{\text {rd }}-1^{\text {st }}$ centuries BC. Ritual, pilgrimage, and the display of complex iconography jointly contributed to the strengthening of new community identities created by the aggregation of pre-existing autonomous settlements under the control of a single town. Shared experiences and collective practices undertaken at territorial sanctuaries (pilgrimages and the deposition of offerings) contributed to endowing the new collective with a clear identity. Moreover figurative images conveyed messages that linked mythical figures to political leaders and to the community's own symbols. All of these elements have been documented in the study region as part of political processes of integration 
Each practice was a distinct ideological strategy involved in the creation of cultural symbols and the fostering of social bonds through religious practices and events. Two political economy strategies were articulated as part of the dualprocessual theory (Blanton et al., 1996 An exclusionary or network strategy involves the production, circulation and use of decorated pottery of a clearly elitist nature, advertising the distinct identities of elites. A corporate strategy emphasizing the fostering of a collective ethos can also be recognised in the shared use of the sanctuaries. The combination of both strategies creates a continuum, not necessarily exclusive (Feinman 2000, 32). In my opinion, this is the case that occurred with the Iberians; both coalition and exclusionary activity characterized the Iberian Iron Age

\section{Acknowledgments}

I thank Lorenzo Abad for images in figure 6. The manuscript has benefited from readings and comments by the editor, three anonymous reviewers, Wendy Cegielski, Mireia López-Bertran and Jaime Vives-Ferrándiz. This work was supported by the MINECO under Grant HAR2012-37003-C03-02

Disclosure statement No potential conflict of interest was reported by the authors

\section{References}

Abad, L. and R. Sanz. 1995. "La cerámica ibérica con decoración figurada de la provincia de Albacete. Iconografía y territorialidad". Saguntum 29: 73-92.

Alcock, S. 2002. Archaeologies of the Greek past. Landscape, monuments, and memories. Cambridge: Cambridge University Press.

Alfayé, S. 2010. "Hacia el lugar de los dioses: aproximación a la peregrinación religiosa en la Hispania indoeuropea". In Viajeros, Peregrinos y aventureros en el Mundo Antiguo, edited by F. Marco Simón, F. Pina Polo and J. Remesal Rodríguez, 177-218. Barcelona: Ed. Univ. Barcelona.

Anderson, B. 1991. Imagined Communities: Relections on the Origins and Spread of Nationalism. $2^{\text {nd }}$ edition. London: Verso.

Aranegui, C., C. Mata and J. Pérez. 1997. Damas y caballeros en la ciudad ibérica. Madrid: Cátedra.

Aranegui, C. 2012. Los Iberos, ayer y hoy. Arqueologías y culturas. Madrid: Marcial Pons.

Blanton, R.E., G.M. Feinman, S.A Kowalewski and P.N. Peregrine. 1996. "A dual-processual theory for the evolution of Mesoamerican civilization". Current Anthropology 37: 1-14

Bonet, H. 1995. El Tossal de Sant Miquel de Llíria. La antigua Edeta y su territorio. Valencia: Diputación Provincial de Valencia.

Bonet, H., I. Grau and J. Vives-Ferrándiz. 2015. "Estructura social y poder en las comunidades ibéricas de la franja central mediterránea". Arqueomediterranea 14: 222 243.

Bourdieu, P. 1980. Le sens práctique. Paris: Editions de Minuit.

Brotons, F. and S. Ramallo. 2010. "Ornamento y símbolo: las ofrendas de oro y plata en el santuario ibérico del Cerro de la Ermita de Encarnación de Caravaca". In La expresión religiosa ibérica: proceso de identidades e intercambios en el marco antiguo Mediterráneo. 'Debate en torno a la religiosidad protohistórica', edited by T. Tortosa and S. Celestino, 123-168. Madrid: Ed. CSIC.

De Polignac, F. 1984. La naissance de la cité grecque. Paris: Éditions la Découverte. DeMarrais, E. 2011. "Figuring the Group". Cambridge Archaeological Journal 21(2): 165-86.

DeMarrais, E., L. J. Castillo and T. Earle. 1996. "Ideology, Materialization and Power strategies". Current Anthropology 37 (1): 15-31. 
DeMarrais, E. and J. Robb. 2013. "Art makes society: an introductory visual essay". World Art 3 (1): 3-22.

Esteban, C. 2013. "Arqueoastronomía y religión ibérica". In Santuarios Iberos: Territorio, ritualidad y memoria, edited by C. Rísquez and C. Rueda, 465-484. Jaén: Ed. A.D.R. El Condado.

Feinman, G. 2000. "Corporate/Network: Perspectives on Models of Political Action and the Puebloan Southwest", In Social theory in Archaeology, edited by M. B. Schiffer, 3151. Salt Lake City: The University of Utah Press.

García Cano, J.M. 1997. Las necrópolis ibéricas de Coimbra del Barranco Ancho (Jumilla, Murcia). I. Las excavaciones y estudio analítico de los materiales. Murcia: Museo de Murcia.

García Cano, J.M. A. Iniesta and V. Page. 1997. "El santuario ibérico de Coimbra del Barranco Ancho (Jumilla, Murcia)". Anales de Prehistoria y Arqueología 7-8: 75-82.

García Cardiel, J. 2014. "La lucha contra la Quimera. La memoria del combate contra el mal en el Sureste ibérico", Studi e Materiali di Storia delle Religioni 80, 2: 615-642.

Grau Mira, I. 2002. La organización del territorio en el área central de la Contestania ibérica. Alicante: Ed. Universidad de Alicante.

Grau Mira, I. 2007. "Los jinetes de la Contestania. Sobre el uso del estilo cerámico como emblema étnico". In Arte Ibérico en la España Mediterranea, edited by L. Abad and J. Soler, 111-125. Alicante: Instituto Alicantino de Cultura Juan Gil-Albert.

Grau Mira, I. 2011. "Landscape dynamics, political processes and social strategies in the Eastern Iberian Iron Age". In Atlantic Europe in the First Millenium: Crossing the divide, edited by T. Moore and X-L. Armada, 153-170. Oxford: Oxford University Press. Grau Mira, I. and I. Amorós. 2013. "La delimitación simbólica de los espacios territoriales ibéricos: el culto en el confín y las cuevas-santuario". In Santuarios Iberos: Territorio, ritualidad y memoria, edited by C. Rísquez and C. Rueda, 183-21. Jaén: A.D.R. El Condado.

Hobsbawm, E. 1983. "Introduction: inventing traditions". In The invention of tradition edited by E. Hobsbawm and T. Ranger, 1-14. Cambridge: Cambridge University Press. Jones, S. 1997. The archaeology of ethnicity. Constructing identities in the past and present. London: Routledge.

Lillo, P., V. Page and J.M. García Cano. 2004. El caballo en la sociedad ibérica: una aproximación al santuario del Cigarralejo. Murcia: Tabularium.

López-Bertran M. and J. Vives-Ferrándiz. 2015. "Miniatures from domestic contexts in Iron Age Iberia". World Archaeology 47 (1): 80-93.

López-Bertran, M. 2011. "Practical Movements: Kinetic Rituals in the Ancient Western Mediterranean”. Journal of Mediterranean Archaeology 24.1: 85-109

Moratalla, J. 2005. "El territorio meridional de la Contestania". In La Contestania Iberica, treinta años después, edited by L. Abad, F. Sala and I. Grau, 91-117. Alicante: Universidad de Alicante.

Morinis, A. 1992. "Introduction: the territory of the anthropology of pilgrimage". In Sacred Journeys: The Anthropology of Pilgrimages, edited by A. Morinis, 1-28. London: Greenwood Press.

Olmos Romera, R. and I. Grau Mira. 2005. "El 'Vas dels Guerrers' de la Serreta". Recerques del Museu d'Alcoi 14: 79-98.

Pérez Ballester, J. 2011. "El poblamiento ibérico del entorno". In La Bastida de les Alcusses. 1928-2010, edited by $\mathrm{H}$. Bonet, J. Vives-Ferrándiz 48-61. Valencia: Diputación Provincial de Valencia.

Pérez Blasco, M. 2011. "Un nuevo estilo pictórico en ceramic ibérica: la necropolis de Poble Nou (Villajoyosa, Alicante)", Lucentum XXX: 87-114.

Quesada, F. 1997. El armamento ibérico. Estudio tipológico, geográfico, funcional, social y simbólico de las armas en la Cultura Ibérica (Siglos VI-I A.C.). Monographies Instrumentum 3. Montagnac: Monique Mergoil. 


\section{REVISED AND ACCEPTED VERSION}

Rouillard, P., A. Espinosa, and J. Moratalla. 2014. Villajoyosa antique (Alicante, Espagne). Territoire et topographie. Le sanctuaire de La Malladeta. Madrid: Casa de Velázquez.

Ruiz Rodríguez, A. 2008. "Iberos". In F. Gracia Alonso (ed.), De Iberia a Hispania, 733844. Madrid: Ariel.

Ruiz, A., and M. Molinos. 1998. The Archaeology of the Iberians. Cambridge: Cambridge University Press.

Sanmartí, J. 2009. "From the archaic states to romanization: a historical and evolutionary perspective on the Iberians". Catalan Historical Review 2: 9-32.

Sallnow, M. J. 1981. "Communitas reconsidered: the sociology of Andean pilgrimage". Man 16: 163-182.

Tortosa, T. and A. Comino. 2013. "Observaciones sobre una nueva mirada en el contexto de los espacios sacros murcianos: el santuario de la Luz (Verdolay, Murcia)". In Santuarios Iberos: Territorio, ritualidad y memoria, edited by C. Rísquez and C. Rueda, 115-144. Jaén: A.D.R. El Condado.

Tortosa, T. 2006. El código iconográfico en la Contestana lbérica. Madrid: Ed. CSIC. Visedo Moltó, C. 1922. Excavaciones en el monte La Serreta, próximo a Alcoy, Memorias de la Junta Superior de Excavaciones Arqueológicas, 41. Madrid: Junta Superior de Excavaciones y Antigüedades.

Yoffee, N. 2007. "Peering into the palimpsest. An introduction to the volume". In Negotiating the past in the past. Identity, memory and landscape in archaeological research edited by N. Yoffee, 1-9. Tucson: The University of Arizona Press. 
Figures

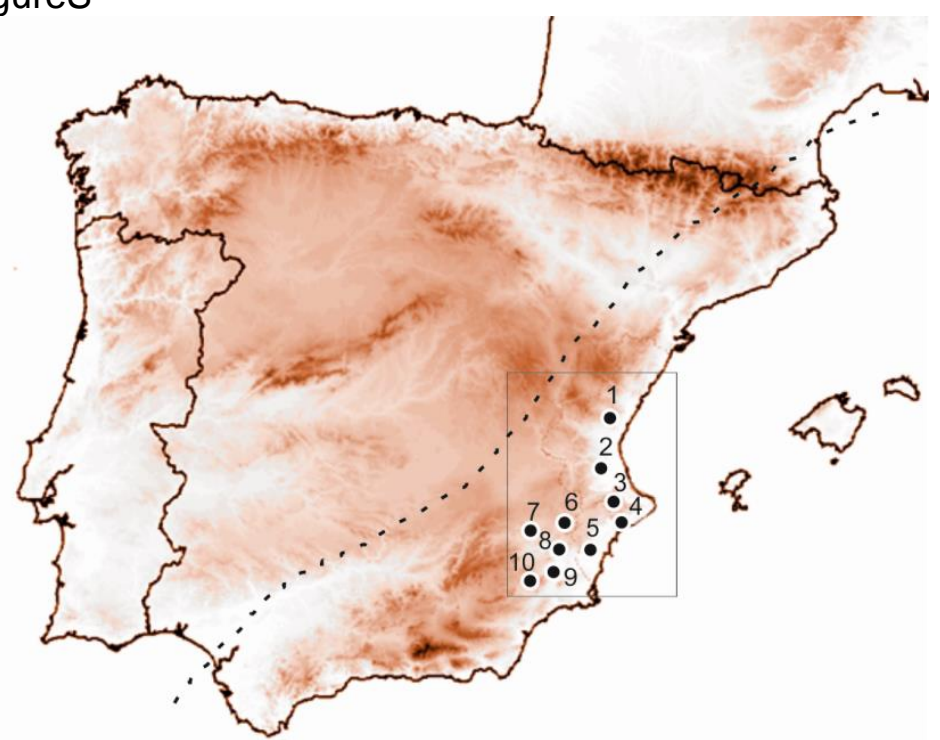

Figure 1. Map showing the main sites mentioned in the text. 1: Edeta; 2: Saitabi; 3: La Serreta; 4: Allone; 5: Ilici; 6: Coimbra del Barranco Ancho; 7: Ilunum; 8: Verdolay; 9: El Cigarralejo; 10: La Encarnación.
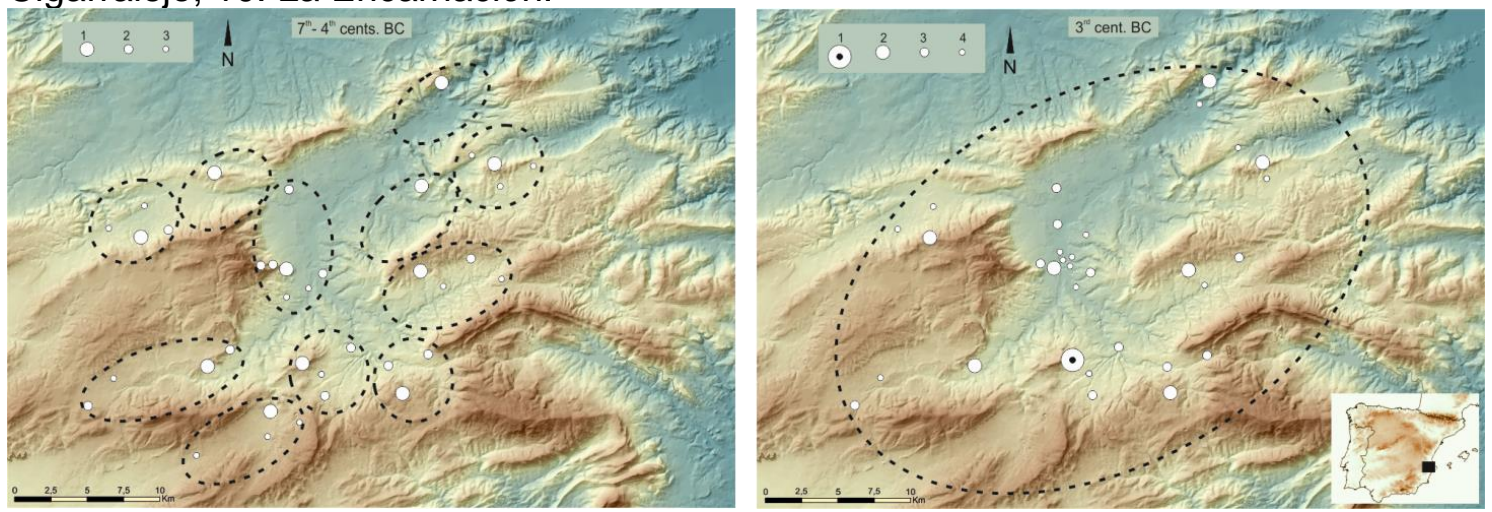

Figure 2. Map of the Alcoi Valley showing the settlement dynamics. Left: local polities during the $7^{\text {th }}-4^{\text {th }}$ cents. BC. Right: the aggregation of several sites into a regional polity during the $3^{\text {rd }}$. cent $B C$. 


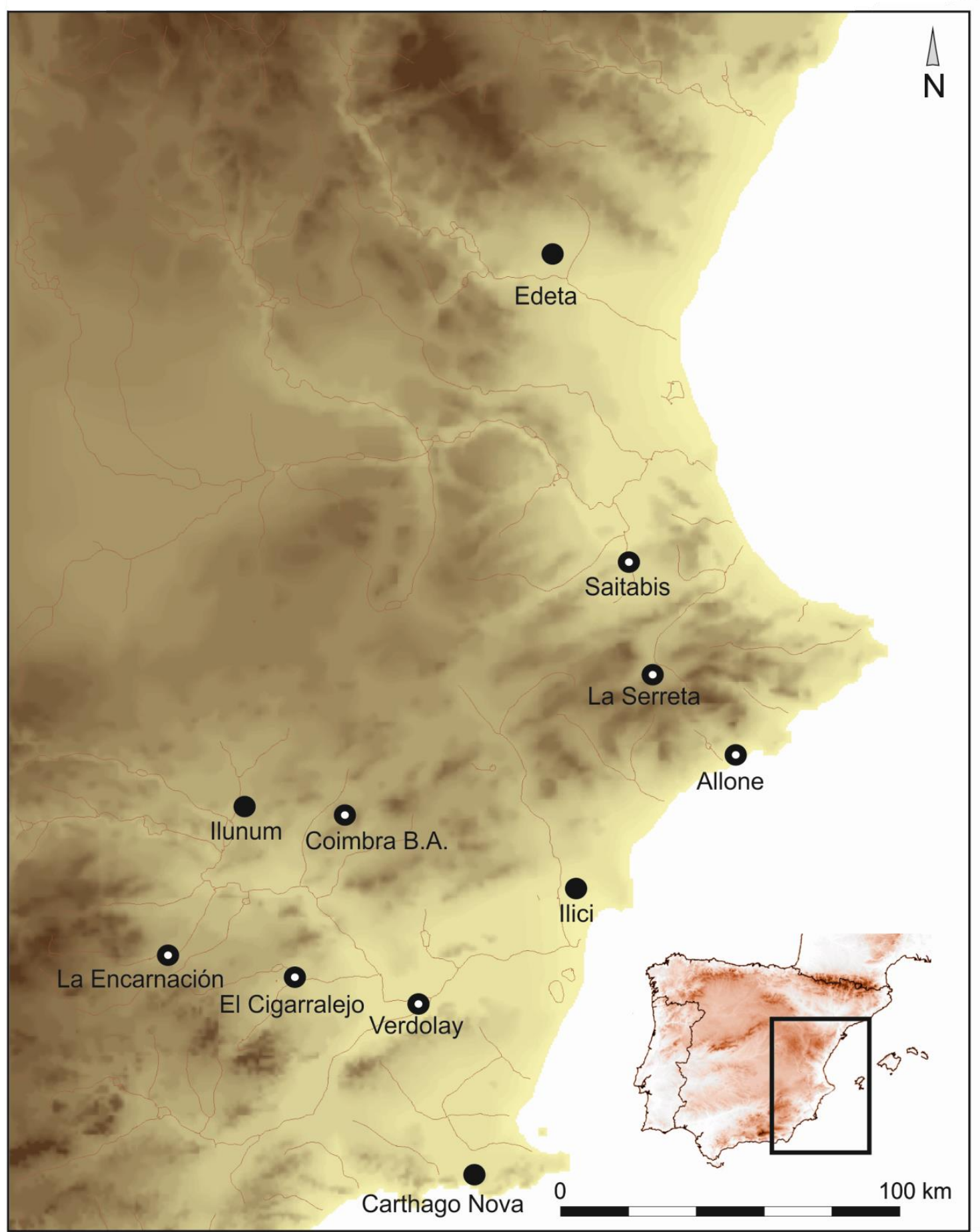

Figure 3. Map showing the main Iberian towns in Eastern Iberia. White dots are towns with local sanctuaries. 


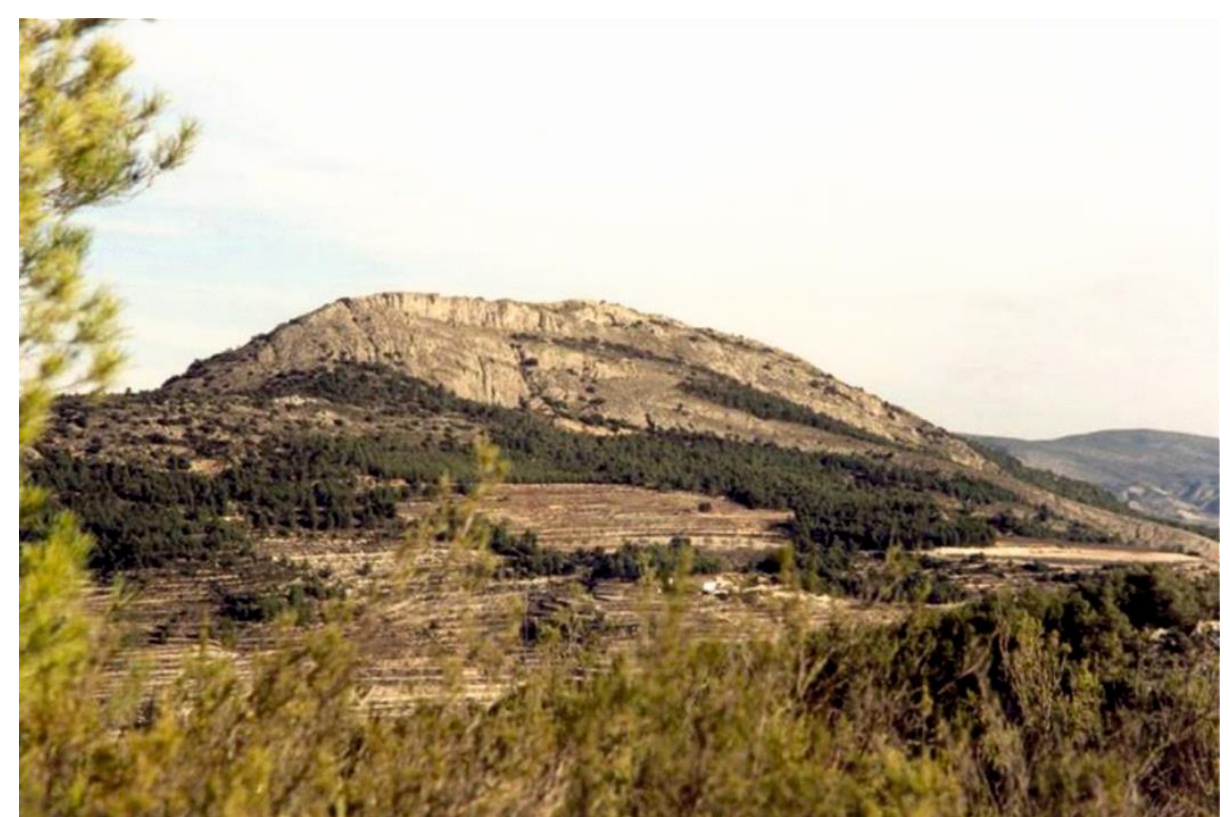

Figure 4. View of the Iberian town and sanctuary of La Serreta d'Alcoi.

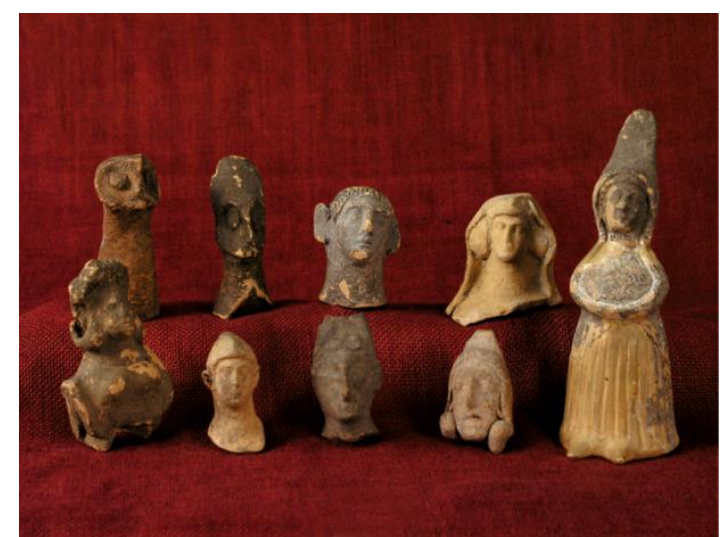

Figure 5. Terracotta figurines from the sanctuary of La Serreta d'Alcoi. The standing figurine in the right has $12 \mathrm{~cm}$ large. (Archaeological Museum 'Camil Visedo' of Alcoi). 

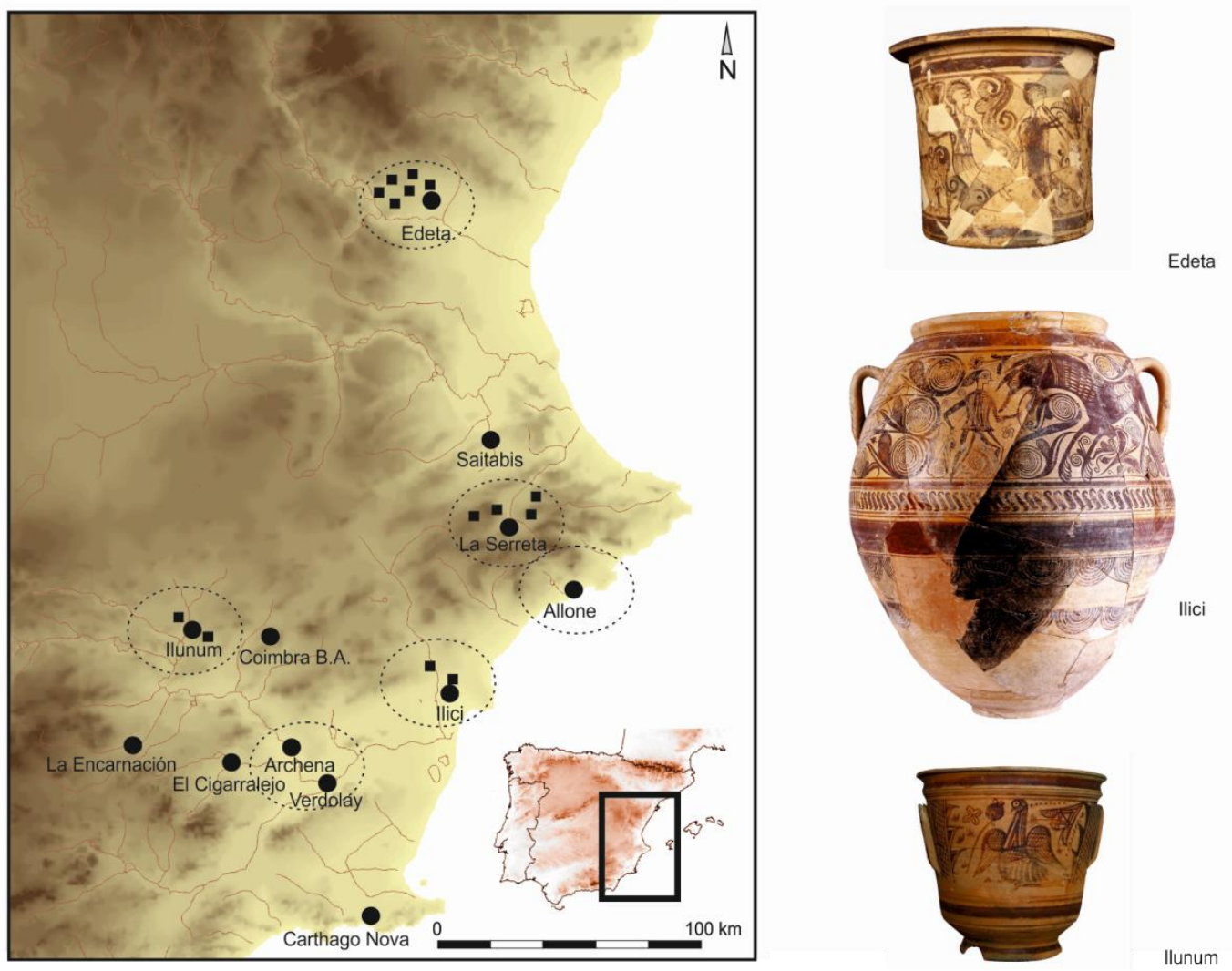

Figure 6. Map showing the main Iberian towns with decorated pottery styles. Each point shows the place of appearance. Examples from the Iberian towns of Edeta (Museum of Prehistory, Valencia), Ilici (University foundation La Alcudia) and Ilunum (provided by L. Abad); different scales.
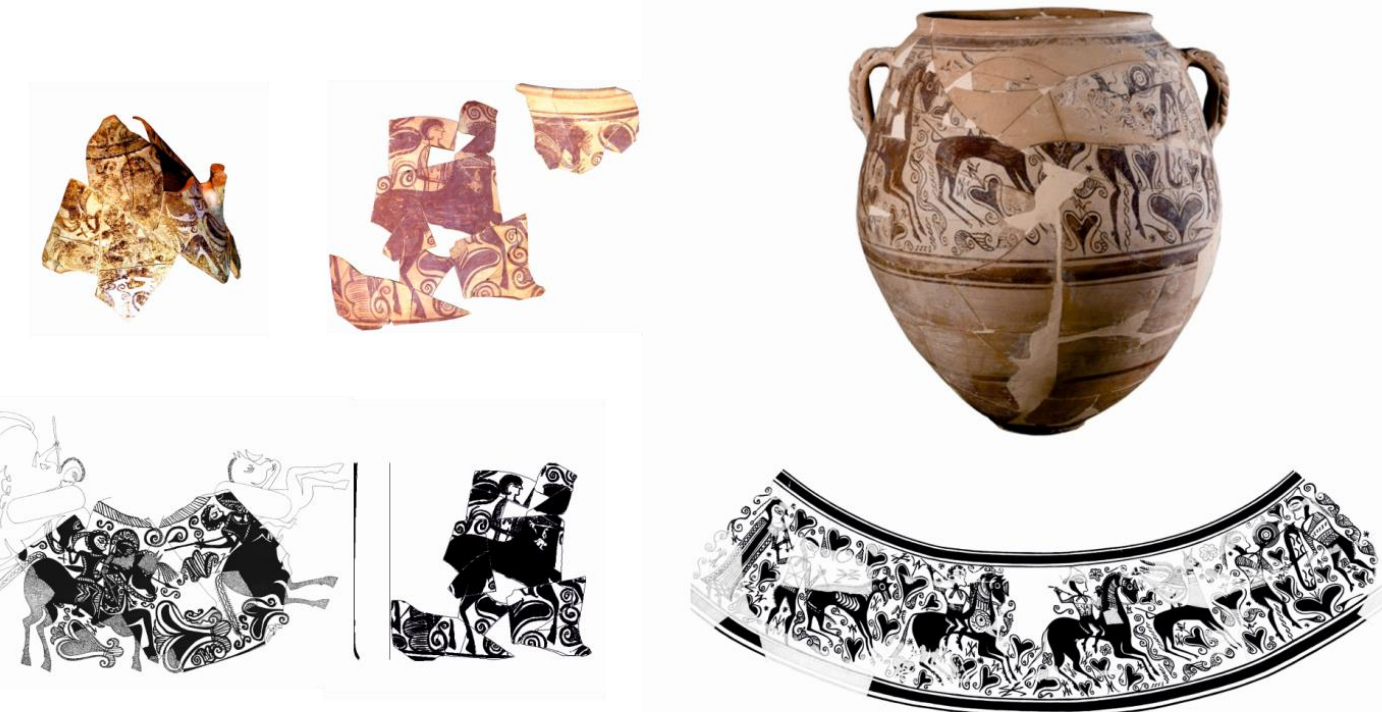

Figure 7. Decorated pottery from the Iberian town of La Serreta d'Alcoi. (Archaeological Museum 'Camil Visedo' of Alcoi). 